\title{
Rancang Bangun Alat Otomatis Pengisian Tangki Air WSLIC Menggunakan Radio Frekuensi di Desa Sukobendu Kecamatan Mantup Kabupaten Lamongan
}

\author{
Zainal Abidin ${ }^{\text {1), }}$ Moh.Andi Bahtiyar Rizqi ${ }^{2)}$ \\ 1) Program Studi Teknik Elektro Universitas Islam Lamongan \\ ${ }^{2)}$ Program Studi Teknik Elektro Universitas Islam Lamongan \\ email : inal9474@gmail.com, andi_m89@yahoo.com
}

\begin{abstract}
Abstrak: Perkembangan teknologi elektronika semakin luas dipergunakan dalam peralatan, mulai dari peralatan yang sangat canggih sampai dengan peralatan yang sederhana, bahkan sampai dengan pekerjaan sehari-hari yang biasa dilakukan di rumah. Air merupakan kebutuhan hidup sehari-hari, ketika air yang di pompa dan ditampung dalam tangki air, manusia hanya menghidupkan pompa ketika tandon air kosong dan mematikan pompa ketika tangki air penuh. Pada umumnya alat otomatis yang digunakan pada tangki air hanya menggunakan saklar yang diberi pelampung yang sistem kerjanya jika air melewati batas atas pengisian maka secara otomatis saklar yang diberi pelampung secara otomatis akan memutus arus. alat yang dibuat menggunakan Radio Frekuensi (RF). Alat ini bekerja menghasilkan sinyal yang dikirim oleh sensor elektroda yang dapat mematikan dan menyalakan pompa secara otomatis sehingga mencegah air tumpah. Alat ini terdiri dari transmitter dan receiver. Bagian trasmitter diletakkan pada tangki air sedangkan bagian receiver pada pompa air. Pengatur nyala atau mati pompa air dapat diatur dengan menggunakan gelombang radio sebagai media pengiriman sinyal perintah. Hal ini lebih efisien untuk jangkauan yang cukup jauh antara tansmitter dengan receiver. Alat ini bisa diterapkan pada WSLIC(Water and Sanitation for Low Income Community). Pada penelitian ini diperoleh hasil jarak alat ini dapat bekerja dengan baik secara optimal adalah 0 sampai 30 meter dan pada jarak 35 sampai 50 meter alat ini tidak dapat mengatur pompa air secara optimal dan diatas 50 alat ini tidak dapat mengatur pompa air
\end{abstract}

Kata Kunci : Sensor, air, WSLIC, radio frekuensi

\section{Pendahuluan}

Perkembangan teknologi elektronika semakin luas dipergunakan dalam berbagai macam peralatan, mulai dari peralatan yang sangat canggih sampai peralatan yang sederhana. Termasuk peralatan rumah tangga yang digunakan sehari-hari peralatan elektronika kalanga rumah tangga yang bekerja secara otomatis yang digunakan khusus untuk aktifitas misalnya dalam menyalakan dan mematikan pompa air.

Air merupakan kebutuhan primer hidup seharihari, pompa air yang digunakan dari dulu sampai sekarang masih kurang efektif. Hal ini dikarenakan pompa air yang digunakan tidak bekerja secara otomatis, ada yang otomatis tetapi membutuhkan kabel yang panjang untuk memasangnya, hal tersebut sebenarnya dapat bekerja dan beroperasi secara otomatis dan tidak membutuhkan kabel, sehingga perlu diciptakan atau dibuat alat yang dapat mengatur sendiri dalam menyelesaikan masalah tersebut, alat yang mampu bekerja secara otomatis dan tidak memerlukan kabel untuk mengoprasikannya. Dalam rangka memberikan kemudahan dalam pengelolaan air terutama untuk distribusi air pada program WSLIC .

Penulisan ini mengambil penelitian atau studi kasus progam WSLIC(Water and Sanitation for Low Income Community) di Desa Sukobendu Kecamatan Mantup Kabupaten Lamongan 


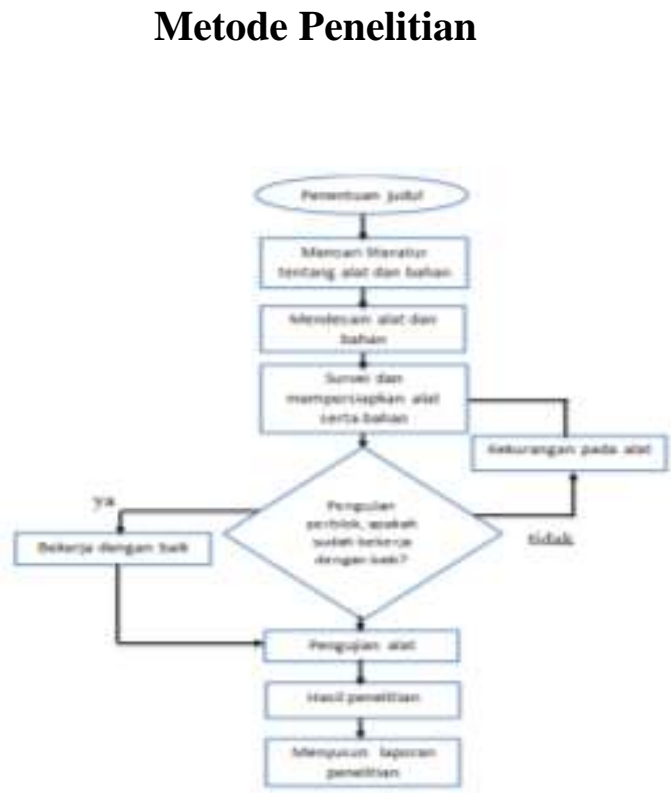

Gambar 1 flow Chart penelitian

Dalam sistem kontrol level air pada WSLIC ini menggunakan beberpa komponen-komponen, berikut adalah alat dan bahan yang di perlukan dalam pembuatan alat kontrol level air otomatis pada WSLIC: plat tembaga, IC 555, PCB lubang, baterai, relay $12 \mathrm{~V}$, transistor BD139, resistor $1 \mathrm{k}$ $\Omega$, dioda zener $2.7 \mathrm{~V}$, kabel pelangi, solder, timah, penyedot timah, trafo 12 Volt $350 \mathrm{~mA}$, elco $100 \mu \mathrm{F} / 50 \mathrm{~V}$, multitester, kristal atau X-TAL $27 \mathrm{MHz}$, dan diode.Alat dan bahan untuk merancang sistem alat kontrol level air air otomatis di butuhkan komponen-komponen: plat tembaga, IC 555, trafo 12 Volt $350 \mathrm{~mA}$, relay 12 $\mathrm{V}$, transistor $\mathrm{BD} 139$, resistor $1 \mathrm{k} \Omega$, rangkaian pemancar, rangkaian penerima, elco $100 \mu \mathrm{F} / 50 \mathrm{~V}$, kristal $27 \mathrm{MHz}$, serta dioda.

\section{Sistem Kerja Alat}

Sistem kerja alat ini yaitu ketika sensor atas elektroda mendapatkan deteksi sinyal maka sensor tersebut akan mengirimkan perintah off kepada pemancar dan kemudian dikirimkan kepada penerima dan kemudian output pada penerima akan menonaktifkan relay untuk mematikan pompa air. Dan ketika sensor bawah mendapat deteksi sinyal maka sensor tersebut akan mengirimkan perintah on kepada pemancar dan kemudian dikirimkan kepada penerima dan kemudian output pada penerima akan mengaktifkan relay yang selanjutnya pompa air tersebut menyala. Untuk sistem kerja alat dapat dilihat pada Gambar 5.

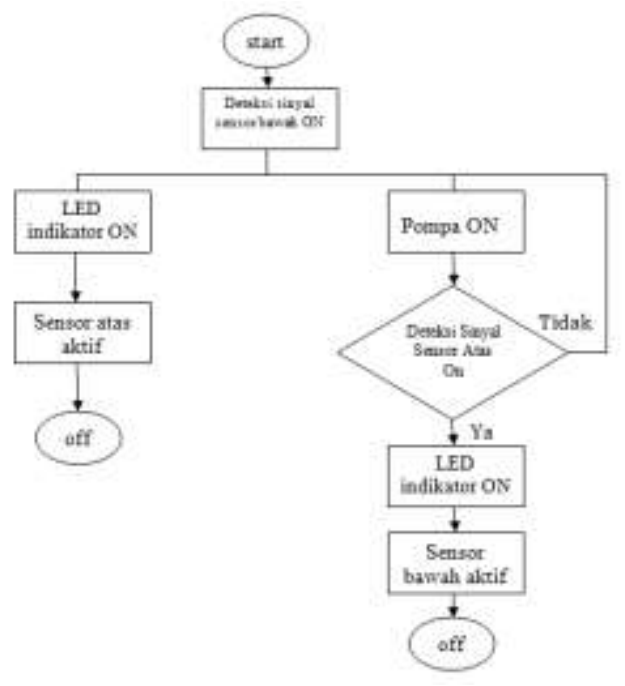

\section{Gambar 2. Sistem kerja alat kontrol level air pada WSLIC}

\section{Perancangan Alat}

\section{Pemancar}

Alat yang digunakan sebagai pengirim sinyal perintah dari sensor elektroda adalah sebuah rangkaian pemancar yang cukup sederhana. Pemancar ini terdiri dari beberapa bagian yang digabungkan sehingga sistem rangkaian dapat bekerja dengan baik.

\section{Perancangan bagian penerima}

Seperti pada rangkaian pemancar, rangkaian penerima juga disusun dari beberapa bagian. Maka pada penerima akan bekerja dengan baik sebagai pengendali otomatis pengontrol level air.

\section{Perancangan bagian sensor}

Sensor adalah sesuatu yang digunakan untuk mendeteksi adanya perubahan lingkungan fisik atau kimia. Variabel keluaran dari sensor yang diubah menjadi besaran listrik disebut Transduser. Pada penelitian ini sensor yang digunakan adalah jenis sensor pasif yaitu menggunakan tiga plat tembaga yang diletakkan pada batas atas dan bawah air yang ada pada tangki air dengan memanfaatkan sifat konduktifitas air, yang menggunakan IC555 sebagai pembaca deteksi sinyal dari plat tembaga tersebut. 


\section{Perancangan bagian power supply}

Power supply adalah perangkat yang berfungsi sebagai pemberi tegangan pada setiap rangkaian. Pada penelitian ini power supply yang dipakai menggunakan trafo $350 \mathrm{~mA}$, dua buah dioda IN41001 serta dua buah elko (elektrolit capasitor) 50 Volt 100 uf dan 16 Volt 100uf.

\section{Hasil dan Pembahasan}

Dalam penelitian ini diperoleh hasil pengujian sebagai berikut :

\section{Pengujian kepekaan sensor}

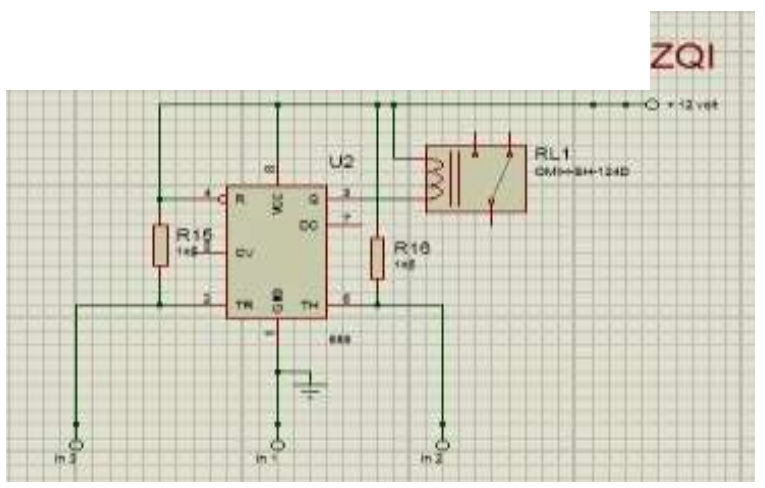

Gambar 3. Sensor level air

Cara kerja rangkaian pada Gambar 6 yaitu naikturunnya level air ada di antara ujung elektroda high dan low, artinya ketika level air turun di bawah elektroda low maka pompa akan $O N$, dan ketika level air naik sampai menyentuh ujung elektroda high maka pompa akan $O F F$. Untuk batas bawah terdapat pada pin 2 dan batas atas pada pin 3 sedangkan pada pin 1 adalah ground

Cara pengujian kepekaan sensor yaitu dengan memberikan catu daya 12 Volt pada saat bagian penerima mendeteksi sinyal, kemudian tegangan output dari IC555 bisa langsung diukur dengan menggunakan multimeter. Berikut tabel pengujian kepekaan sensor menggunakan mulitmeter. Untuk hasil pengujian dapat dilihat pada Tabel 1

Tabel 1. Data hasil pengujian sensor elektoda

\begin{tabular}{ccc}
\hline No & $\begin{array}{c}\text { Tinggi air } \\
\text { pada bak }\end{array}$ & $\begin{array}{c}\text { TeganganKeluaran } \\
\text { sensor elektroda }(\mathrm{V})\end{array}$ \\
\hline 1 & $1,5 \mathrm{~cm}$ & 3,8 \\
\hline 2 & $24 \mathrm{~cm}$ & 4,8 \\
\hline
\end{tabular}

\section{Pengujian rangkaian pemancar}

Dalam pengujian pemancar ini kita akan mengukur besar tegangan dan bentuk sinyal output pemancar menggunakan osiloskop, untuk skema pemancar dapat dilihat pada Gambar 7.

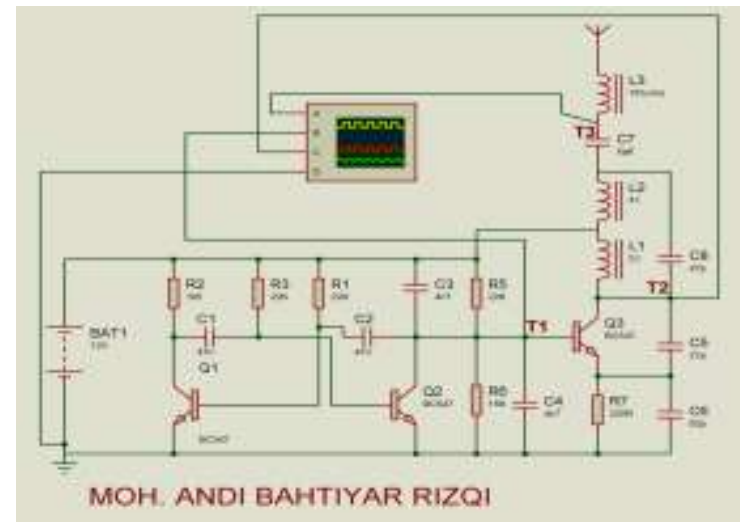

Gambar 4. Skema pemancar

Pengujian pada bagian-bagian:

- Blok pembangkit pulsa(T1)

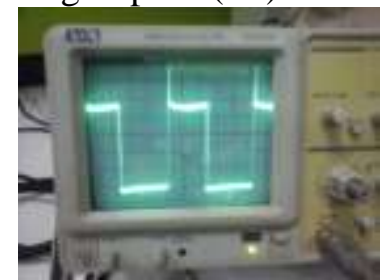

\section{Gambar 5. Hasil gelombang pembangkit pulsa}

Pada Gambar 5 pengujian bagian pembangkit pulsa sinyal yang dibangkitkan oleh transistor BC547 hasil keluaran dari kaki colector adalah berupa pulsa. Untuk tegangan terukur 12 Volt dari baterai.

- Blok osilator RF(T2)

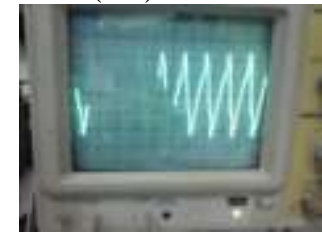

\section{Gambar 6. Hasil gelombang osilator RF}

Pada Gambar 6 pengujian Osilator RF dihasilkan gelombang RF dengan frekuensi $27 \mathrm{MHz}$ dari kristal. Gelombang RF digunakan untuk mengirim sinyal pulsa dari pemacar menuju ke penerima.

- Blok penguat akhir(T3) 


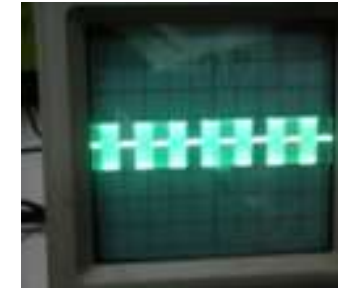

\section{Gambar 7. Output gelombang pemancar}

Penguat akhir adalah rangkaian akhir dari pemancar yang bertugas untuk menguatkan sinyal pulsa dan gelombang RF. Pada Gambar 10 output penguat akhir, pulsa yang dibangkitkan akan dimodulasikan pada gelombang RF kemudian dikuatkan untuk dikirim pada penerima

\section{Pengujian rangkaian penerima}

Seperti yang telah dilakukan pada rangkaian pemancar, Dalam pengujian penerima ini kita akan mengukur besar tegangan dan bentuk sinyal output penerima menggunakan osiloskop, untuk skema penerima dapat dilihat pada Gambar 8

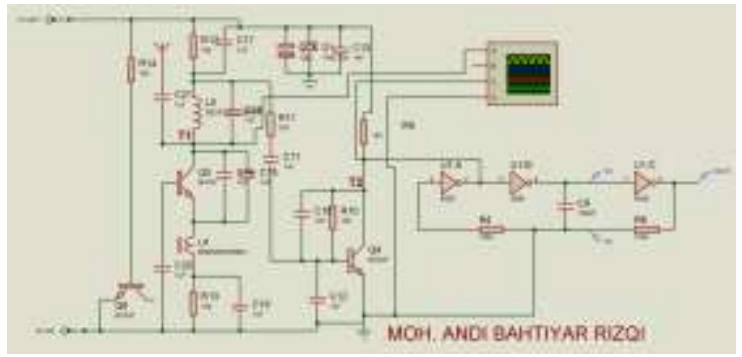

\section{Gambar 8. Skema penerima}

Pengujian pada bagian-bagian:

- Blok Penerima gelombang RF(TI)

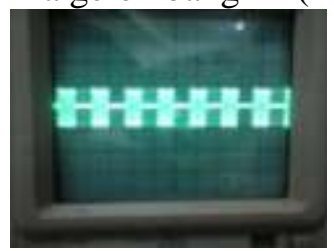

\section{Gambar 9. Gelombang pada penerima}

Pada Gambar 9 pengujian pada penerima gelombang RF Sinyal yang terukur memiliki Bentuk gelombang yang sama separti gelombang yang dipancarkan oleh pemancar yaitu sinyal yang dikeluarkan oleh penguat akhir.

- Blok pemisah sinyal(T2)

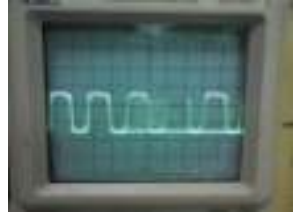

Gambar 10. Hasil gelombang yang dipisahkan

Pada Gambar 10 pengujian bagian pemisah sinyal ini Gelombang RF yang diterima kemudian dipisahkan dan selanjutnya pulsa pulsa yang ada didalamnya akan dipisahkan oleh transistor BC547 sesuai dengan jumlah pulsa. Bentuk gelombang setelah dipisahkan akan menjadi seperti bentuk gelombang yang dibangkitkan pembangkit pulsa pada rangkaian pemancar.

\section{Pengujian alat kontrol level air otomatis WSLIC}

Pengujian alat kontrol level air otomatis dengan memanfaatkan radio frekuensi pada WSLIC secara keseluruhan ini dilakukan dengan menggabungkan semua peralatan ke dalam sebuah sistem yang terintegrasi. Tujuannya untuk mengetahui bahwa rangkaianyang dirancang telah bekerja dengan baik.

Tabel 2. Pengujian saat pompa ON

\begin{tabular}{ccccc}
\hline No & $\begin{array}{c}\text { Perc } \\
\text { oban }\end{array}$ & $\begin{array}{c}\text { Sensor } \\
(\text { Volt })\end{array}$ & Pompa(Volt $)$ & $\begin{array}{c}\text { Kondisi } \\
\text { pompa }\end{array}$ \\
\hline 1 & 1 & 6,78 & 219 & Kerja \\
\hline 2 & 2 & 6,80 & 220 & Kerja \\
\hline 3 & 3 & 6,89 & 220 & Kerja \\
\hline
\end{tabular}

Dari Tabel 2 untuk pengujian pertama tegangan pada sensor terukur 6,78 Volt pada pompa 219 Volt dan kondisi pompa kerja, kemudiam pada pengujian kedua tegangan pada sensor terukur 6,80 Volt paa pompa 220 Volt dan kondisi pompa kerja, kemudian pada pengujian yang ketiga tegangan pada sensor terukur pada sensor 6,89 Volt pada pompa 220 Volt kemudian kondisi pompa kerja.

\section{Tabel 3. Pengujian saat pompa OFF}

\begin{tabular}{ccccc}
\hline $\mathrm{N}$ & Perco & Sensor( & Pompa & Kondisi \\
o & ban & Volt $)$ & & pompa
\end{tabular}




\begin{tabular}{lllll}
\hline & & & $($ Volt $)$ & \\
\hline 1 & 1 & 9,80 & 0,1 & Mati \\
\hline 2 & 2 & 9,77 & 0,1 & Mati \\
\hline 3 & 3 & 9,79 & 0,1 & Mati \\
\hline
\end{tabular}

Dari Tabel 3 untuk pengujian pertama tegangan pada sensor terukur 9,80 Volt pada pompa 0,1 Volt dan kondisi pompa mati, kemudiam pada pengujian kedua tegangan pada sensor terukur 9,77 Volt paa pompa 0,1 Volt dan kondisi pompa mati, kemudian pada pengujian yang ketiga tegangan pada sensor terukur pada sensor 9,79 Volt pada pompa 0,1 Volt kemudian kondisi pompa mati.

\section{Tabel 4. Pengujian jarak jangkauan alat}

\begin{tabular}{cc}
\hline $\begin{array}{c}\text { Jarak Jangkauan alat } \\
\text { Pemancar \& penerima } \\
\text { (meter) }\end{array}$ & Pompa air \\
\hline 0 & Menyala \\
\hline 5 & Menyala \\
\hline 10 & Menyala \\
\hline 15 & Menyala \\
\hline 20 & Menyala \\
\hline 25 & Menyala \\
\hline 30 & Menyala \\
\hline 35 & Terkadang Menyala \\
\hline 40 & Terkadang Menyala \\
\hline 45 & Terkadang Menyala \\
\hline 50 & Terkadang Menyala \\
\hline$>50$ & Tidak Menyala \\
\hline
\end{tabular}

Dari pengujian Tabel 4 tersebut dapat disimpulkan pada jarak 0 sampai 30 meter pompa air dapat bekerja secara optimal dan pada jarak 35 sampai 50 meter pompa air terkadang menyala dan terkadag tidak menyala dan untuk jaraj diatas
50 meter pompa air tersebut sudah tidak bisa menyala

\section{Simpulan}

Dalam membuat alat kontrol level air otomatis yang memanfaatkan radio frekuensi adalah dengan memnfaatkan radio frekuensi sebagai media penghubung antara sensor elektoda dan pompa air adalah dengan menghubungkan sensor elektroda pada pemancar yang kemudian sinyal dari sensor tersebut akan dikirim oleh pemancar yang akan diterima oleh bagian penerima(receiver), yang kemudian perintah dari sensor tersebut akan diterjemahkan dalam bentuk tegangan yang digunakan untuk menggerakkan relay yang akan menyalakan pompa air

Alat ini pada jarak 0 sampai 30 meter dapat mengatur pompa air secara optimal, dan pada jarak 35 sampai 50 alat ini tidak dapat mengatur pompa air secara optimal terkadang pompa menyala dan terkadang pompa tidak bisa menyala, kemudian pada jarak diatas 50 meter alat tidak dapat mengatur pompa air.

\section{Daftar Pustaka}

1. Drs RM Francis D. Yuri, 1995. Teknik Merakit dan Service Radio Remote Control

2. Haryanto, 2007, kendali motor pompa berdasarkan ketinggian air dengan sensor elektroda.skripsi, Universitas Negeri Semarang, Semarang

3. Handy Wicaksono, 2009, Catatan Kuliah"Automasi", Universitas Kristen Petra

4. Mohammad Thoif, 2006, pengendali pintu gerbang dan garasi Secara otomatis.skripsi, Univeritas Negeri Semarang, Semarang.

5. Jayadin Ahmad, 2007. Elektronika dasar.

6. http://indoorhydroponicveggies.wordpress.co $\underline{\mathrm{m} / \# \text { waterleveldetector }}$ 